\title{
The Universal Kriging Mapping of the Neogene EL-markers Rs5 and $\Delta$, Northern Croatia
}

\section{Kartiranje z univerzalnim krigiranjem neogenskih EL-markerjev Rs5 in $\Delta$ v severni Hrvaški}

\author{
Ivana Mesić Kiš' , Tomislav Malvić \\ ${ }^{1}$ ES kralja Tomislava Našice, Ulica Matice hrvatske 1, 31500 Našice, Croatia \\ 2 University of Zagreb, Faculty of Mining, Geology and Petroleum Engineering, Pierottijeva 16, 10000 Zagreb, Croatia; \\ * ivy.mesic@gmail.com
}

\begin{abstract}
The area of the Bjelovar Subdepression in Northern Croatia, which represents the southwestern part of Drava's depression, has been analysed. More than 700 depth data were collected in a regular grid covering the existing structural maps of e-log markers Rs5, Z' and $\Delta$, with cells $2 \times 2 \mathrm{~km}$ in size. For zonal assessment, Thiessen polygon method was used as introductory analysis preceding Kriging interpolation on regional scale. The emphasis was on OK and UK interpolation, their comparison and selection of most appropriate method for mapping. Crossvalidation results proved UK technique to be the most appropriate in mapping of e-log markers Rs 5 and $\Delta$, thus acquiring the most accurate maps so far of the analysed Neogene area.
\end{abstract}

Key words: e-log markers, advanced mapping method, Universal Kriging, Bjelovar Subdepression, Croatia

\section{Povzetek}

Analizirali smo območje bjelovarske poddepresije v severni Hrvaški, ki predstavlja jugozahodni del dravske depresije. Zbrali smo nad 700 globinskih podatkov v pravilni meži, ki pokriva obstoječe strukturne karte e-log markerjev Rs5, Z' in $\Delta$ s celicami velikosti $2 \times 2 \mathrm{~km}$. Za ugotovitev zonalnosti smo uporabili Thiessnovo poligonsko metodo kot uvodno analizo pred krigirno interpolacijo v regionalnem merilu. Poudarek je bil na OK in UK interpolacijah, njuni primerjavi in izbiri najprimernejše metode kartiranja. Navzkrižna preverba rezultatov je potrdila, da je UK tehnika najprimernejša za e-log markerje Rs5 in $\Delta$, kar je omogočilo dobiti najnatančnejše karte analiziranega neogenskega območja do zdaj.

Ključne besede: e-log markerji, sodobna metoda kartiranja, univerzalno krigiranje, bjelovarska poddepresija, Hrvaška 


\section{Introduction}

First geological explorations of the Bjelovar Subdepression began in the mid-19th century when first sketches and geological maps were made in this area (e.g. [1]). In the 20th century and in recent years the research was mostly directed towards detecting hydrocarbon reservoirs (e.g., [2-4]). E-log markers were used for the interpretation of the geological evolution. They represent layers between two sedimentary or igneous-metamorphic units in the overlaying cover and basement. Over the last 15 years in the area of Bjelovar subdepression, depth maps were made on surfaces of all e-log markers (Rs7, Rs5, Z', $\Delta$ and D') and one e-log border (Pt/Tg) that divides the Neogene-Quaternary sediments and older rocks in their basement (e.g. [5]). Maps were interpolated by hand $[3,6]$, while some e-log markers (Rs7 and Rs5) and e-log border (Pt/Tg) were also interpolated using Ordinary Kriging (abbr. OK) technique [7]. This technique was confirmed by numerous Croatian authors as the best method for displaying the spatial distribution of clastic reservoir variables (e.g. [8-11]).

The Universal Kriging technique (abbr. UK), also known as a Kriging with a trend, is slowly finding its place in Croatian geology. It was used for mapping of e-log marker Z' in Šandrovac Field,
Croatian biggest and prominent oil and gas field [12], when compared to the OK, gave much better results $($ RMSE $(O K)=171$, RMSE $(U K)=59)$ due to expressed linear spatial trend. The aim of this paper is to show and explain why the UK technique gives better results for two e-log markers, Rs5 (Lower/Upper Pannonian border) and $\Delta$ (the upper part of Upper Pontian) and provides most accurate depth maps so far for analysed Neogene area. In addition, e-log marker Z' had been interpolated (Upper Pannonian/Lower Pontian border) using both $\mathrm{OK}$ and UK for better insight of OK and UK differences. The mapped area of Bjelovar Subdepression is located in the northern part of Croatia, i.e. it is the south-western part of Drava Depression, approximately between $45^{\circ} 20^{\prime}$ and $46^{\circ} 5^{\prime} \mathrm{N}$, $16^{\circ} 20^{\prime}$ and $17^{\circ} 25^{\prime}$ E (Figure 1 ).

\section{Materials and methods for data selection and interpolation}

Mapping of the entire Subdepression was done using the square grid cells $(2 \times 2 \mathrm{~km}$ in size $)$ that were laid over the hand interpolated maps (e.g. [7]) of e-log markers Rs5, Z' and $\Delta$ (Figure 2) made by [6]. Thiessen polygon method was used for zonal estimation and also as an apparent indicator of regular grid used in

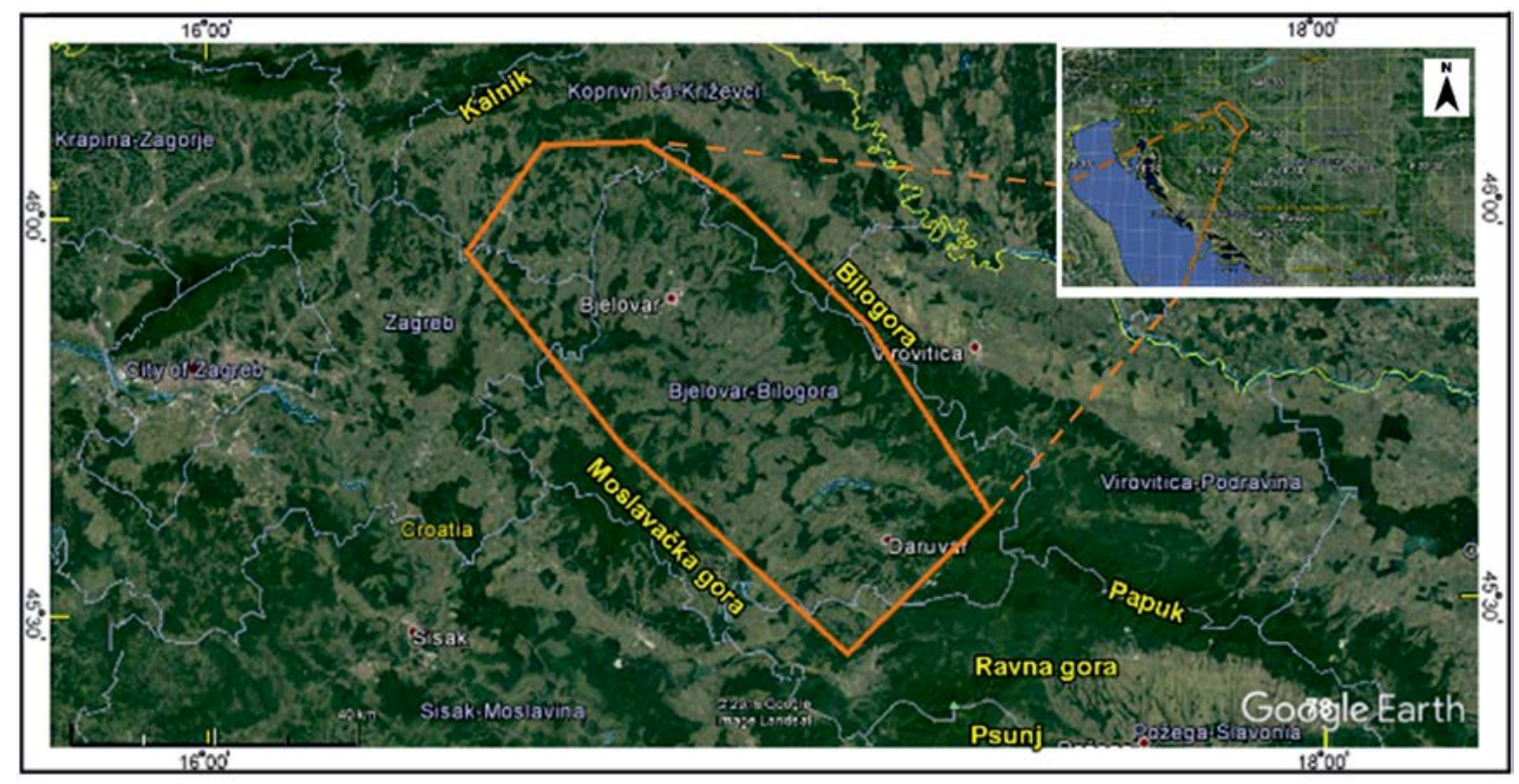

Figure 1: Geographical location of Bjelovar Subdepression (SW part of Drava Depression, Northern Croatia). 

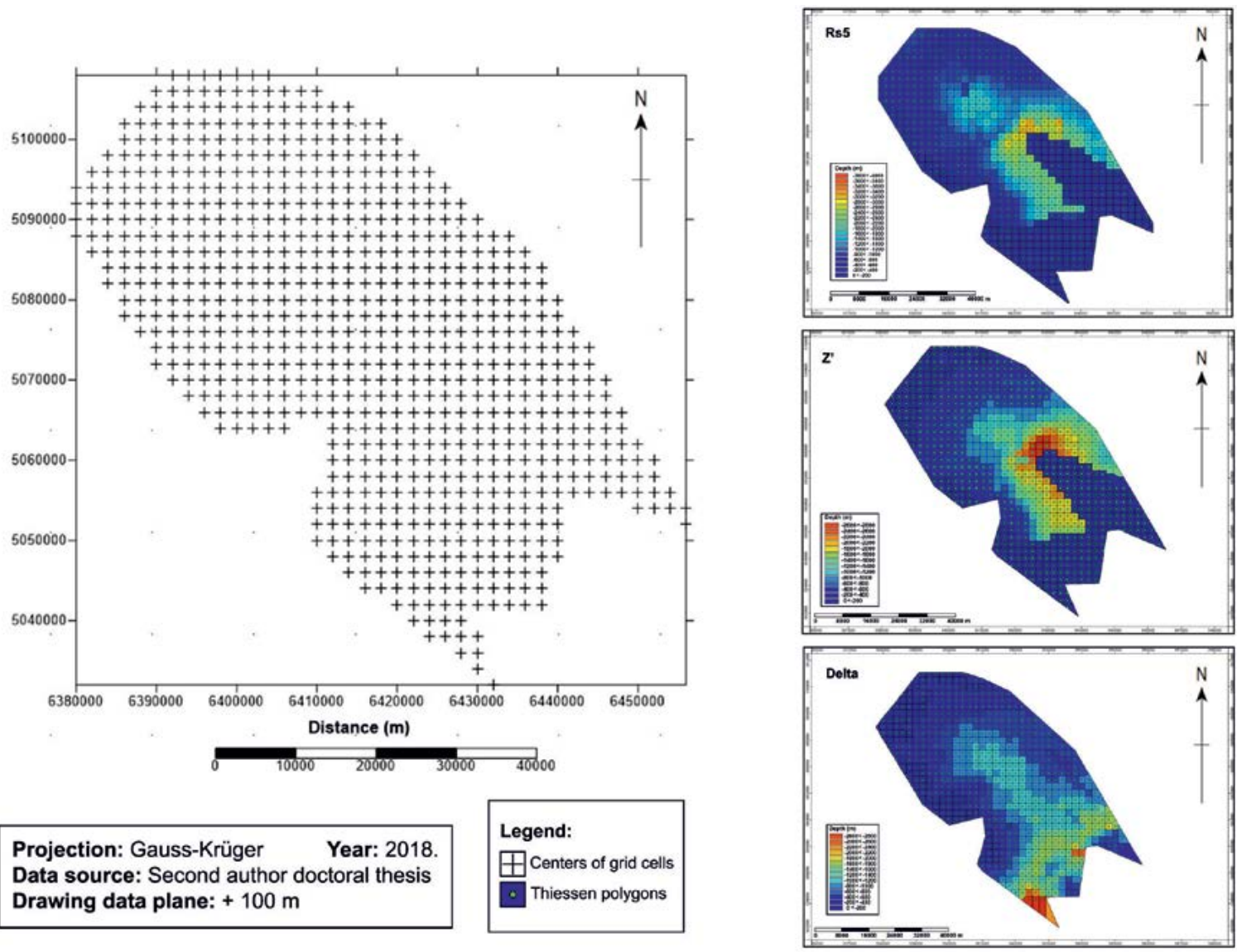

Figure 2: Regular grid and centers of grid cells covering Bjelovar Subdepression mapping area with Thiessen polygon maps of e-log markers Rs5, Z' and $\Delta$.

mapping of afore-mentioned e-log markers. Given method was firstly used for computing the average rainfall over given area (e.g., [13]), and has been described in detail in numerous papers (e.g., [14-17]) where a polygon of influence (known as Thiessen or Voronoi polygon) is constructed in such a way that its geometry will include all data points that are closer to the sample compared to any other measurements. These polygons (or diagrams) of influence are described by all midpoints between each neighbouring sample data [14].

Zonal estimation was done using open source software, SAGA GIS, for Thiessen polygons computation. Thiessen polygon maps (Figure 2) allowed a quick assessment of depth values over the entire mapped area, even of non-sampled areas. Each polygon has a point value that represents centre of a grid cell.

\section{Applied Kriging techniques and results}

Kriging represents an advanced statistical estimation method and one of the most common deterministic interpolation methods used to estimate the values of regionalized variables in selected points, which are assigned a relevant weighting coefficient that represents the influence of a particular data on the value of the final estimation at the selected grid node. A regionalized variable is also random variable, but where grid of point data for selected (geological) variable can (with certainty) represent a statistically fully representative sample for a particular volume (e.g. rocks) that is analysed. Kriging methods were preceded by the determination of spatial dependencies, i.e. the variogram analysis that took into account directions of observation (directional variograms), data accumulation (clusters), and in the OK local variance, which is calculated only from data within the search ellipse. 
The interpolation using $\mathrm{OK}$ and $\mathrm{UK}$ techniques was done in Surfer 13, which was preceded by variogram analysis in Variowin 2.1.0., a freeware for spatial data analysis created by [18].

\section{The Ordinary Kriging (OK) maps}

$\mathrm{OK}$ is one of the most commonly used Kriging techniques, which premise is constant unknown mean in the local neighbourhood of each estimation point. Variogram surface map for the variable "depth" was created (Figure 3) using following parameters: lag spacing (h) $=2000 \mathrm{~m}$, number of lags $=20$, angular tolerance $=45^{\circ}$. Given map shows two axes, blue coloured primary (direction $120^{\circ}-300^{\circ}$ ) and red coloured secondary (direction $30^{\circ}-210^{\circ}$ ). However, the choice between primary and secondary axis could also be based on the structural map, especially if number of variogram pairs is less than 10 by each lag (e.g., [6]). In such case it is assumed that variogram axes corresponded highly with the regional structural axis of analysed structure.

Structural map of e-log marker Rs5 [6] showed unconformity on the east of the subdepression, which affected the data number and consequently made the regional range value smaller. Unconformity can be also easily seen on Thiessen polygon maps (Figure 2), where unavailable data were displayed as dark blue polygons (centroids were given value 0). Experimental variogram of the primary axis shows range value of $15000 \mathrm{~m}$, which is expected since it reflects the reduction of the sedimentary basin at the end of the Lower Pannonian and at the beginning of the Upper Pannonian (i.e. transition from Paratethys into Pannonian Lake). Variogram model was approximated using spherical model with following parameters: nugget $=11200$, range $=18000 \mathrm{~m}$, sill $=560000$ (Figure 4 ).

Structural map of e-log marker Z' also showed large unconformity on the eastern part [6]. It represents Upper Pannonian/Lower Pontian boundary which is a classic example of lake deposition in Croatian part of Pannonian Basin System (abbr. CPBS). It defines period of 2. transtension when huge amounts of clastites were transported by turbidites from Eastern Alps to CPBS (e.g., $[2,6,19,20,21]$ ) resulting in deposition of numerous and thicker sandstone members. Experimental variogram of

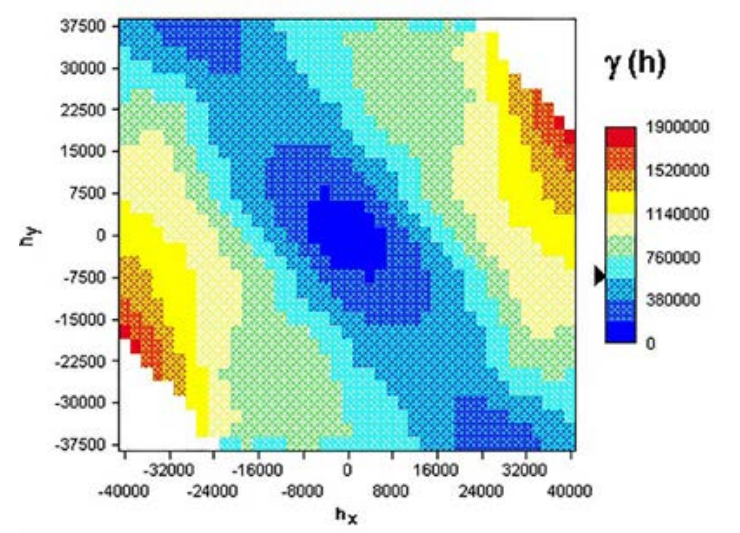

Figure 3: The variogram surface map for variable "depth".
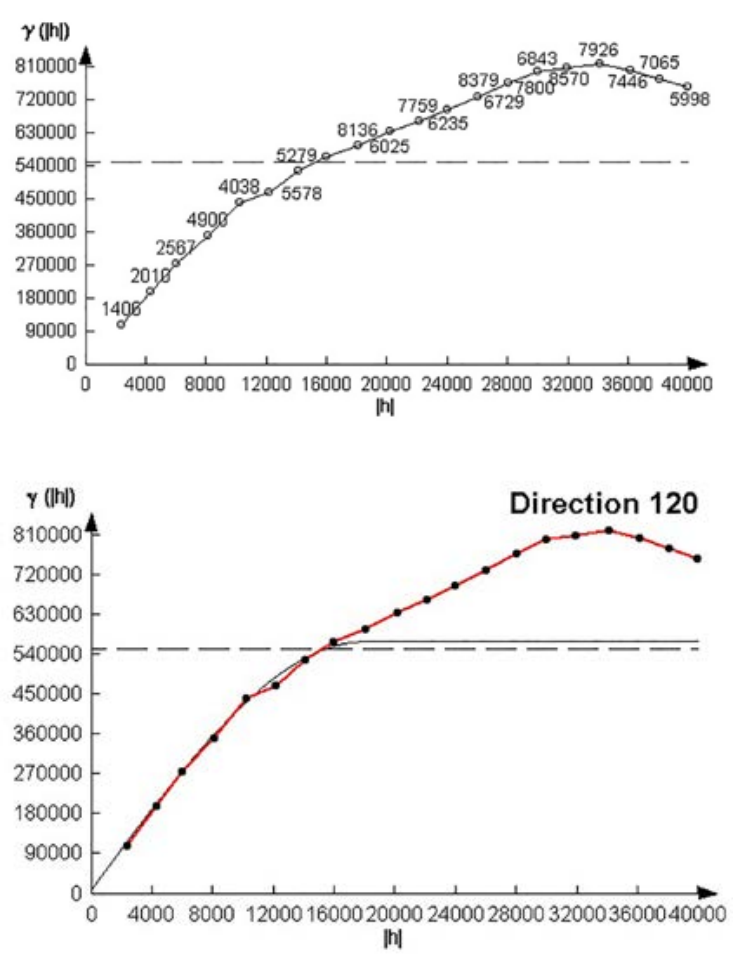

Figure 4: Experimental variogram of the primary axis for e-log marker Rs5 (up), and corresponding theoretical spherical model (down).

the primary axis was again approximated using spherical model with following parameters: nugget $=72000$, range $=24000 \mathrm{~m}$, sill $=450000$ (Figure 5). A somewhat larger range is the result of the turbidity currents being the main transport mechanism at that time.

Structural map of e-log marker $\Delta$ represents transition from $2^{\text {nd }}$ transtension to $2^{\text {nd }}$ transpression tectonic phase [6]. The Bjelovar Sub- 

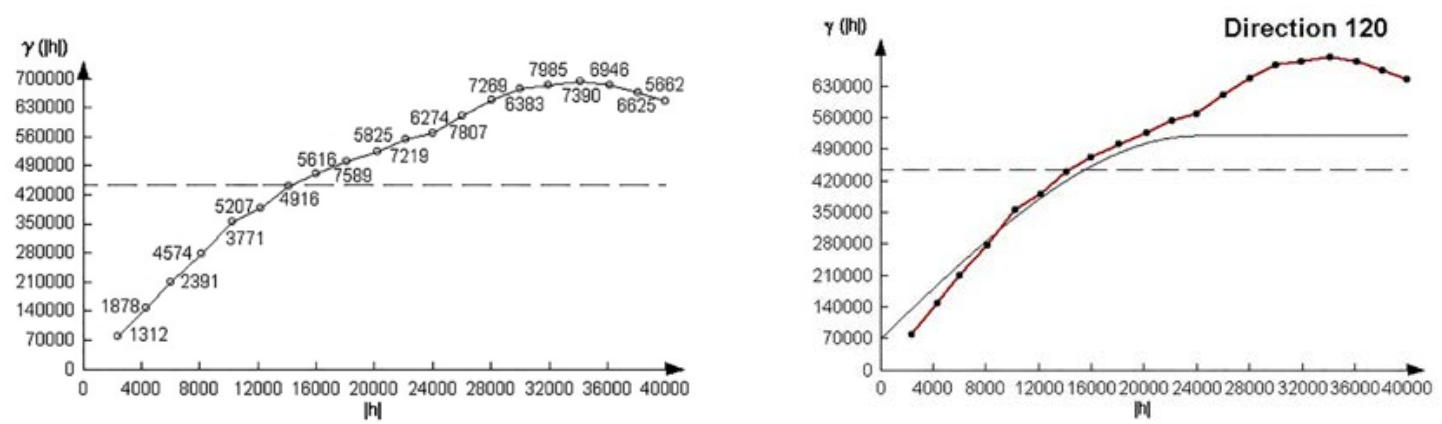

Figure 5: Experimental variogram of the primary axis for e-log marker $Z^{\prime}(l e f t)$, and corresponding theoretical spherical model (right).
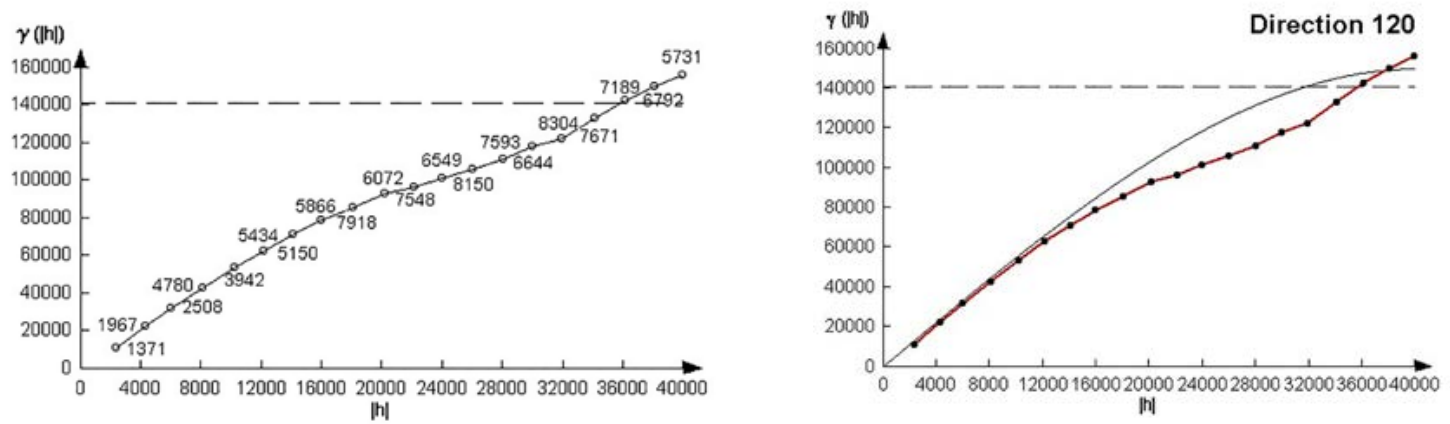

Figure 6: Experimental variogram of the primary axis for e-log marker $\Delta$ (left), and corresponding theoretical spherical model (right).
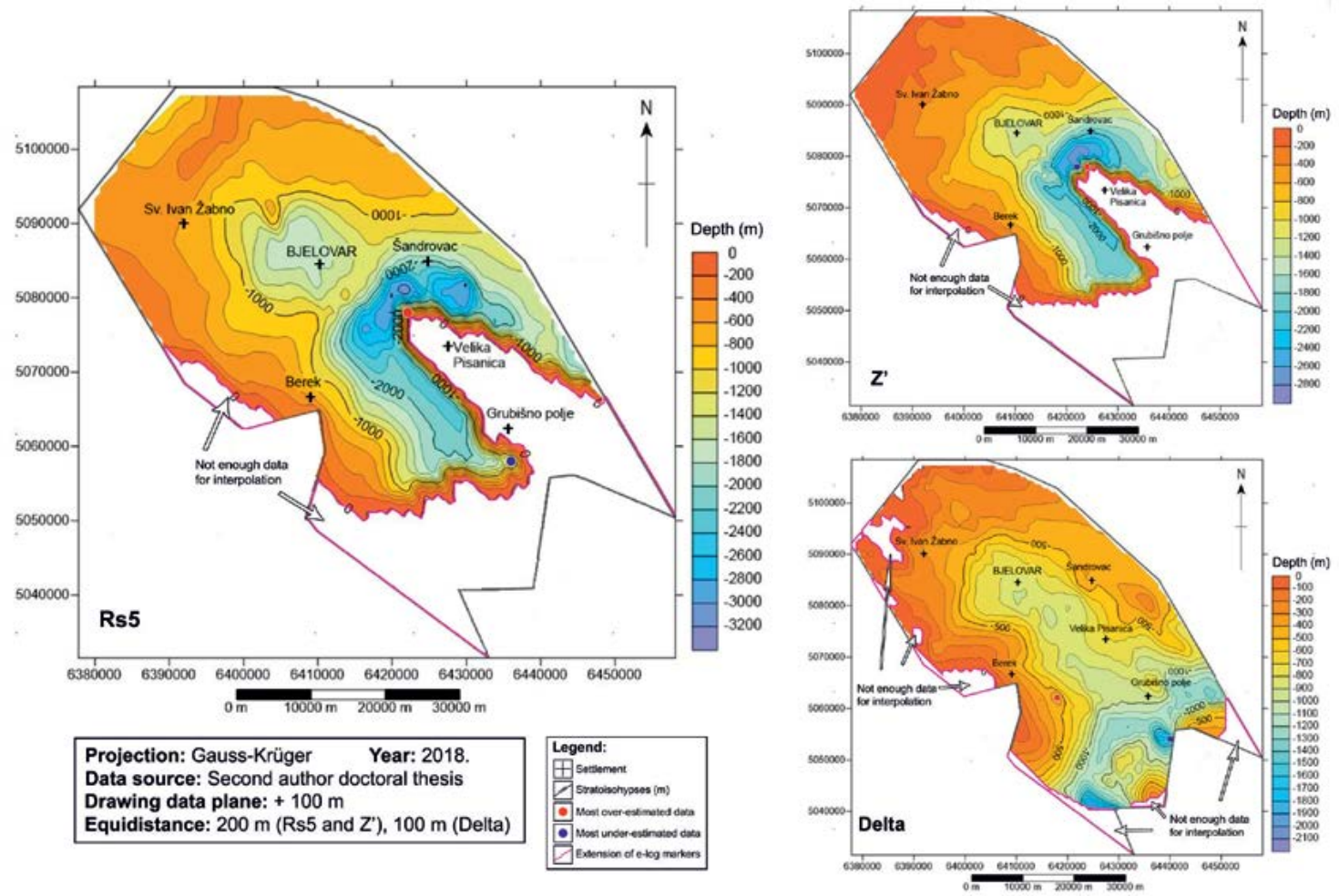

Figure 7: The Ordinary Kriging structural maps of e-log markers $R s 5, Z^{\prime}$ and $\Delta$. 
depression was significantly less characterised with differences among highs and lows than on deeper maps. Experimental variogram of the primary axis was, once again, approximated using spherical model with following parameters: nugget $=0$, range $=40000 \mathrm{~m}$, sill $=150000$ (Figure 6). These are the highest range values, indicating a large spatial dependency of the data. Figure 7 shows structural maps of e-log markers Rs5, Z' and $\Delta$ interpolated using $\mathrm{OK}$ technique. This set of maps had been considered as improvements regarding the previously made regional subdepressional maps interpolated by hand $[2,6]$, but also a necessary set of OK maps that could be compared with the same UK map set, performed with the same input dataset, program and analysis (Figure 14).

As mentioned before, unconformity in the eastern part of the subdepression is easily seen on structural maps of e-log marker Rs5 and Z'. It reflects the reduction of the sedimentary basin, which caused a much smaller regional variogram range. The largest present-day depth of approximately $3000 \mathrm{~m}$ was recorded in the central part of the subdepression where also in past a deeper part of the lake was situated during the Pannonian/Pontian transition. On contrary, present-day margins of the subdepression, especially in the north, were shallow, or even inland. Today values at Lower/Upper Pontian border are mostly $<1000 \mathrm{~m}$, with exception in the SW. Compared with previous maps, present depth values that are three times lesser, still indicating further shallowing in thepast.

\section{The Universal Kriging (UK) maps}

UK technique implies a trend in data, which in this case represents any detectable tendency for the values to change as a function of the coordinate variables. This technique assumes nonstationary regionalized variable (the mean value varies and is not constant). According to [22], it can be considered having two components: drift (average or expected value of the regionalized variable) and a residual (difference between the actual measurements and the drift). The process of using UK can be described through the following steps:

1. Understanding of trend appearance based on the nature of our data,

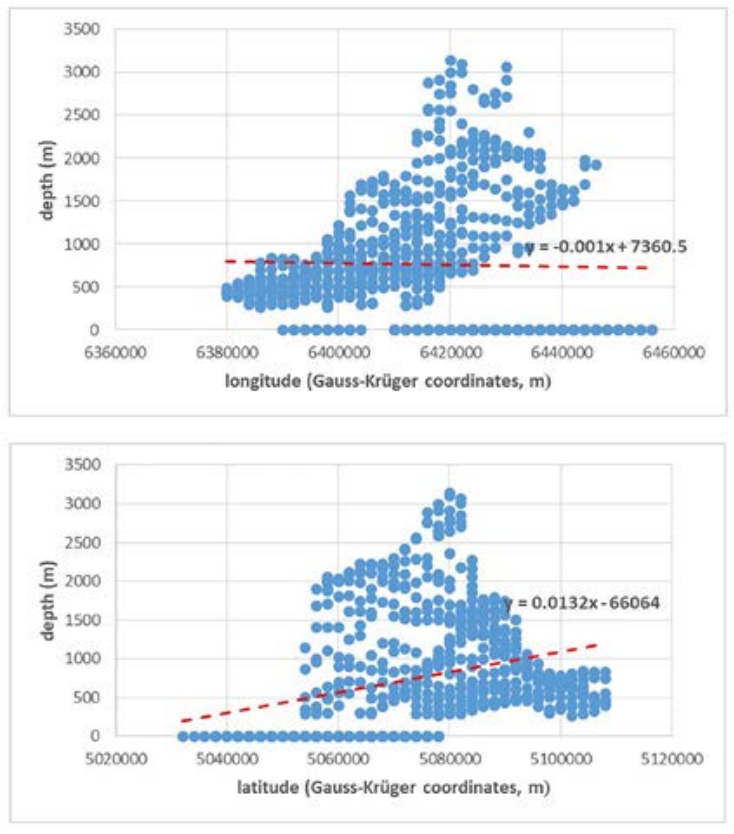

Figure 8: Depth values read from structural map of e-log marker Rs5.

2. Using a simple form of the trend if possible and avoiding extrapolation beyond available data,

3. Subtracting the trend from the observed data to obtain the residuals,

4. Variogram computation and spatial estimation of residuals,

5. Adding back the kriged residuals to the trend (e.g., [17]).

The spatial dependence of data can be displayed using simple scatter diagram. Figure 8 shows scatter plot with barely noticeable negative linear trend of depth with longitude and positive with latitude. It represents a set of 743 data of e-log marker Rs5. However, as mentioned before, due to large unconformity in the eastern part of the subdepression, set of 232 depth data were given value 0 . If only the 511 absolute depth values were taken into consideration, Pearson's correlation coefficient of the longitude and depth is $-0.35\left(\mathrm{R}^{2}=0.13\right)$, and the latitude and depth $0.66\left(\mathrm{R}^{2}=0.44\right)$, which means that the linear bond in this case is of "medium strength" (Figure 8).

Depth data set of e-log marker Z' counts 720 data points. In this case, only 497 absolute 

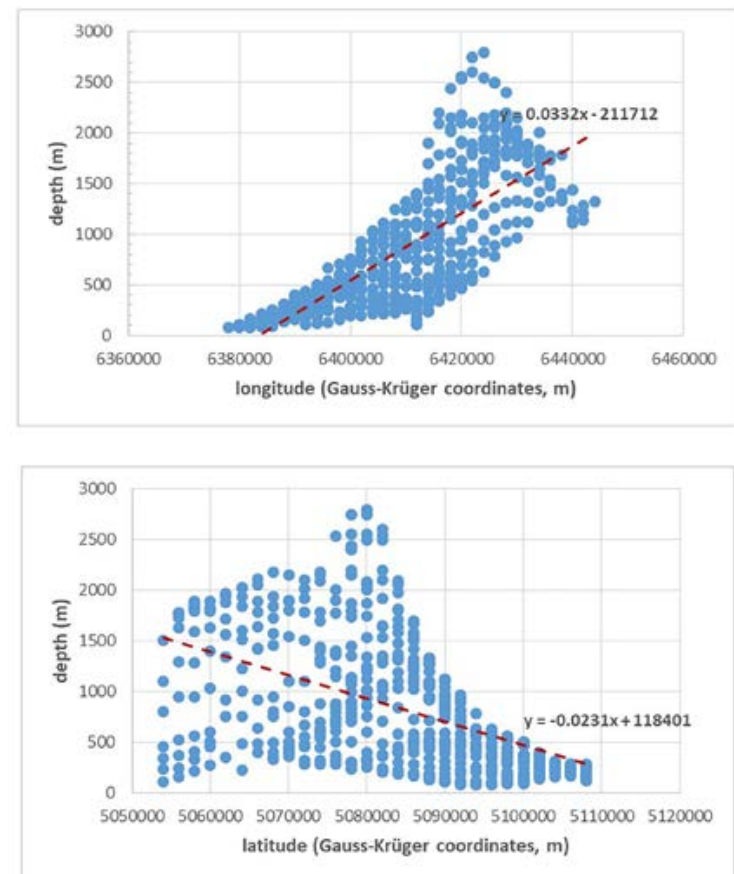

Figure 9: Depth values read from structural map of e-log marker Z'.
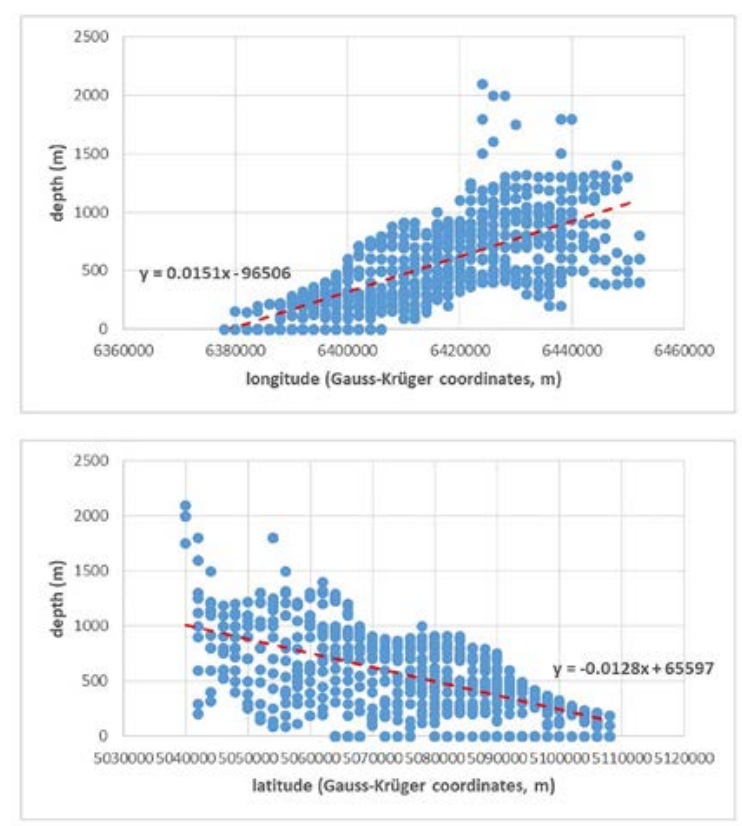

Figure 10: Depth values read from structural map of e-log marker $\Delta$.

depth values read from the structural map are shown in scatter plot for a better trend view (Figure 9). The linear bond is stronger in terms of the strong linkage of the depth with the lat-
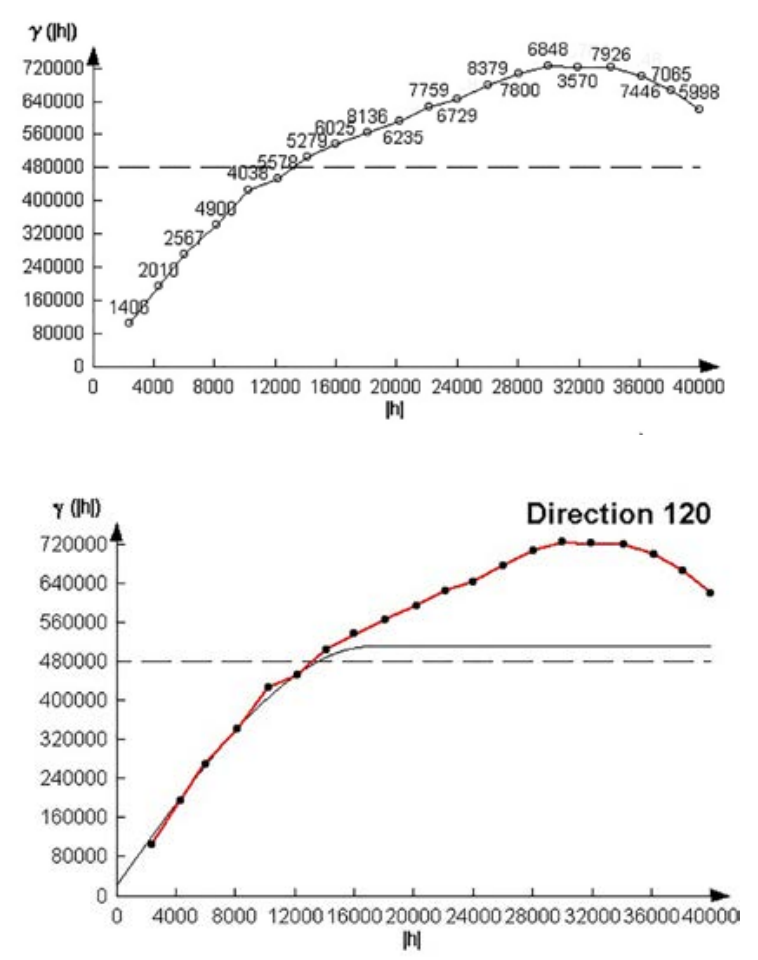

Figure 11: Experimental variogram of the primary axis for variable "residuals" for e-log marker Rs5 (up), and corresponding spherical theoretical model (down).

itude where $r=0.76\left(R^{2}=0.57\right)$ and with the longitude where $r=-0.49\left(R^{2}=0.23\right)$.

The depth values of the e-log marker $\Delta$ (set of 727 data of which 689 are absolute values) show a clear positive linear trend (Figure 10) with longitude $\left(r=0.68, R^{2}=0.47\right)$, and a negative with the latitude $\left(r=-0.58 ; R^{2}=0.34\right)$.

After trend determination, multiple regression analysis (since there are two independent variables - longitude and latitude) is performed to obtain the variable "residuals" for the variogram computation. The result are the variograms of residuals for e-log markers Rs5, Z' and $\Delta$ that follow bellow.

Unaltered parameters of lag spacing $(2000 \mathrm{~m})$, number of lags $(20)$, angular tolerance $\left(45^{\circ}\right)$, direction of primary $\left(120^{\circ}-300^{\circ}\right)$ and secondary axis $\left(30^{\circ}-210^{\circ}\right)$ were used. For residual data of e-log marker Rs5, experimental variogram of the primary axis was approximated using spherical model (Figure 11) with following parameters: nugget $=0$, range $=17200 \mathrm{~m}$, sill $=490000$, where every parameter had a lower value compared to OK technique. 

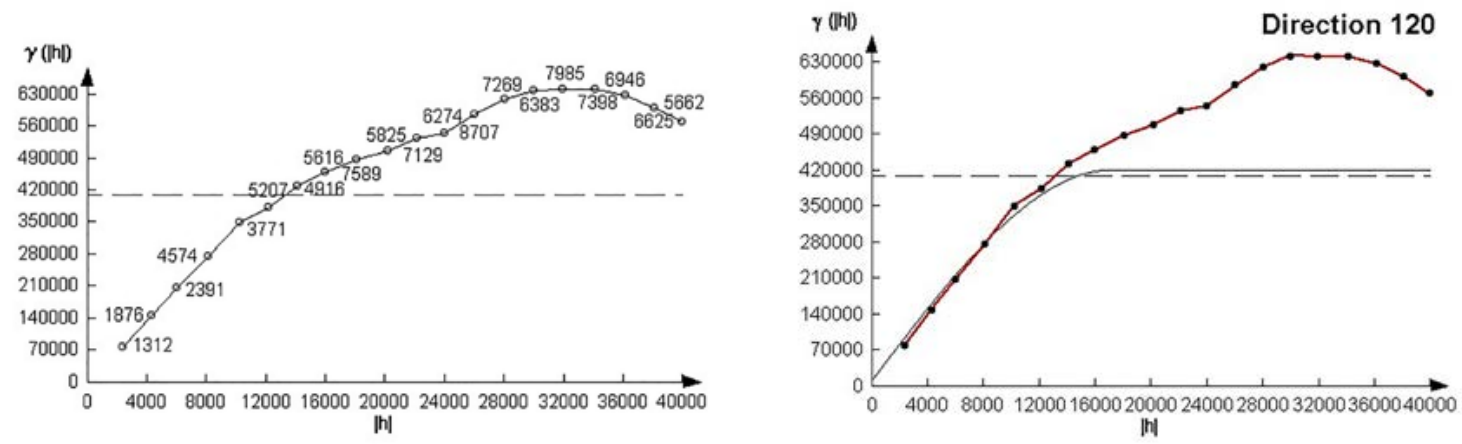

Figure 12: Experimental variogram of the primary axis for variable "residuals" for e-log marker Z' (left), and corresponding spherical theoretical model (right).
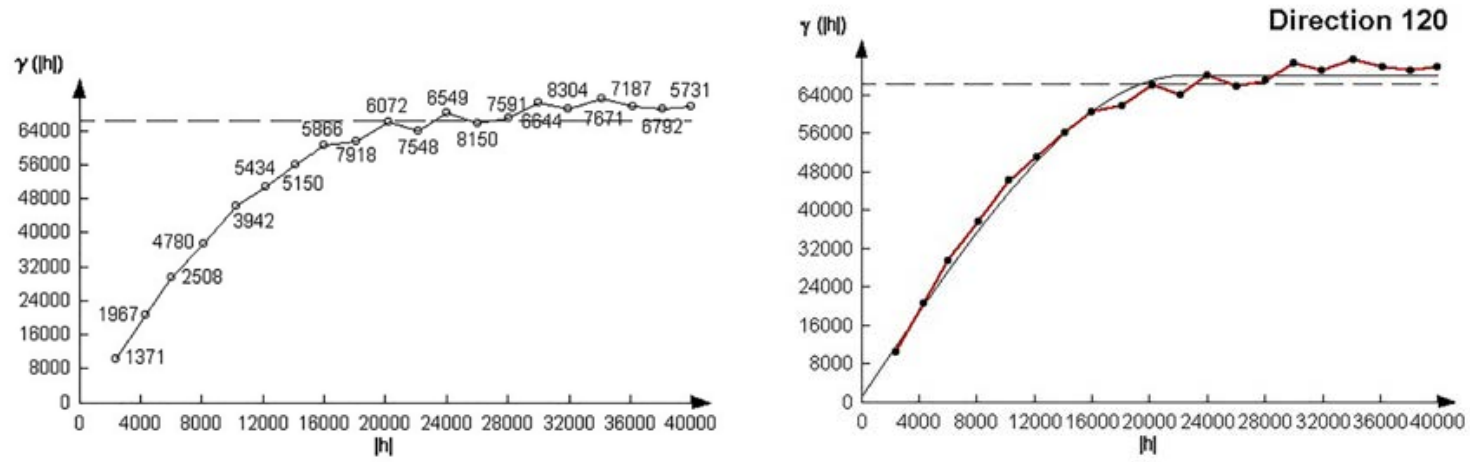

Figure 13: Experimental variogram of the primary axis for variable "residuals" for e-log marker $\Delta$ (left), and corresponding spherical theoretical model (right).
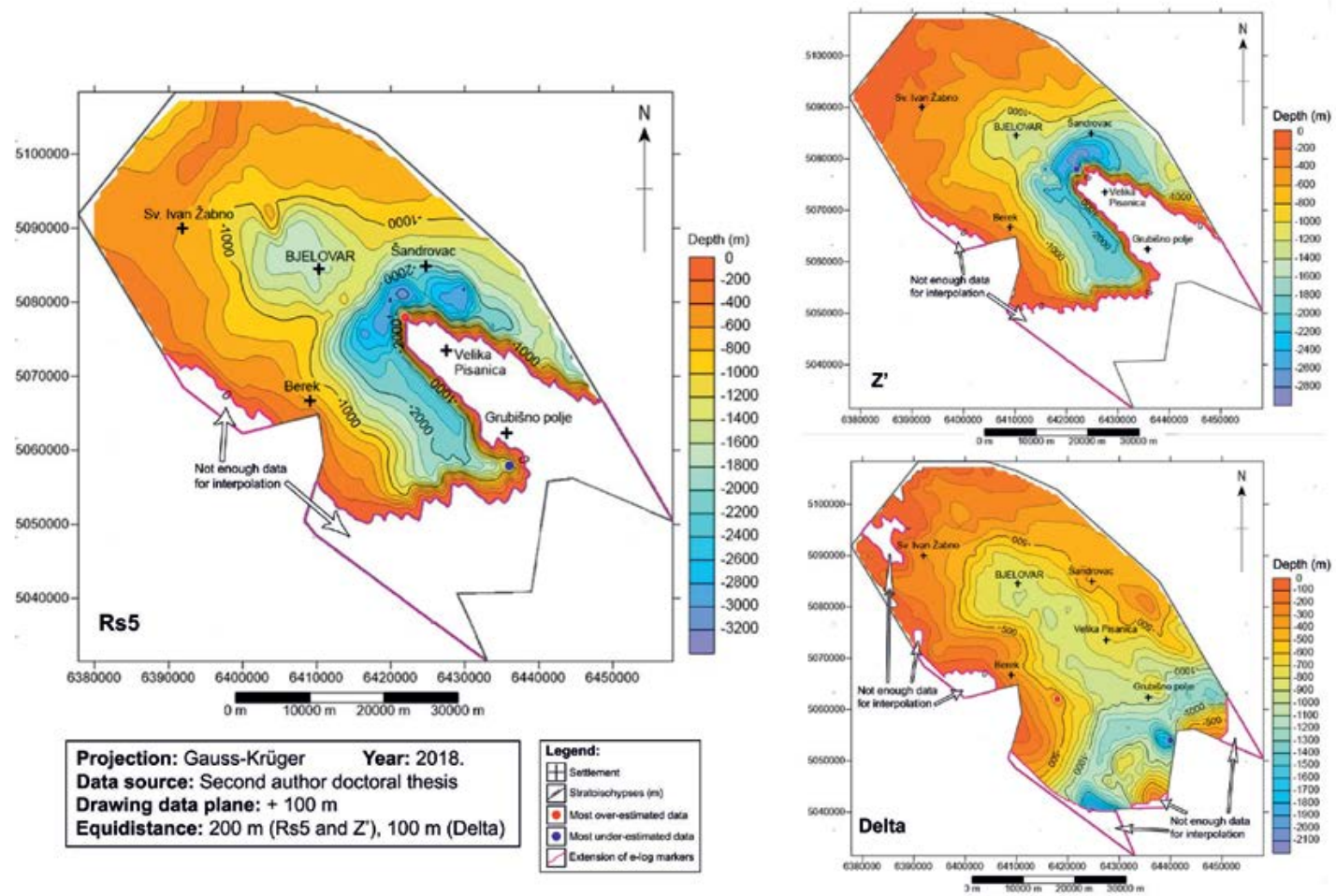

Figure 14: The Universal Kriging structural maps of e-log markers $R s 5, Z^{\prime}$ and $\Delta$. 
Experimental variogram of e-log marker Z' for residual data of the primary axis and its approximation with spherical models is shown in Figure 12. Range is equal to previous variogram of residual data of e-log marker Rs5 $(17200 \mathrm{~m})$, while the nugget is 12300 , and the sill 41000 .

For residual data of e-log marker $\Delta$, experimental variogram of the primary axis was approximated using, as in all previous examples, spherical model (Figure 13). Input data for UK technique were as follows: nugget $=1340$, range $=22400 \mathrm{~m}$, sill $=67000$.

UK map of e-log marker Rs5 (Figure 14) gives smaller crossvalidation value $(\mathrm{RMSE}=267.9)$ compared to the OK map (RMSE $=268.2$ ). Most over-estimated data is for both maps at the same coordinates $(X=6435993, Y=5057986)$, where the measured value of the "depth" variable is $1880 \mathrm{~m}$ and the estimated value of the "depth" variable for OK amounts $157.7 \mathrm{~m}$ and UK $152.8 \mathrm{~m}$. The same goes for most under-estimated data with coordinates at $\mathrm{X}=6421993$, $Y=5077986$, where the original value of the "depth" variable is $0 \mathrm{~m}$ and the estimated by $\mathrm{OK}=1568.8 \mathrm{~m}$, while with UK $=1567.6 \mathrm{~m}$ (Figures 7 and 14).

In case of e-log marker Z', OK technique has smaller crossvalidation value ( $\mathrm{RMSE}=237.9)$, compared to UK (RMSE $=238.6)$. UK map shows identical coordinates of most over-estimated $(\mathrm{X}=6424000, \mathrm{Y}=5078000)$ and under-estimated data $(X=6422000, Y=5078000)$ as do OK map (Figures 7 and 14), next to unconformity line. Original value of most over-estimated data is $0 \mathrm{~m}$, while estimation made by $\mathrm{OK}$ and UK is $1416.2 \mathrm{~m}$ and $1424.1 \mathrm{~m}$. Most under-estimated data has original value of $2750 \mathrm{~m}$, while $\mathrm{OK}$ and UK techniques made estimations of $1327.17 \mathrm{~m}$ and $1320.5 \mathrm{~m}$.

Finally, UK map of e-log marker $\Delta$ also resulted with lesser crossvalidation value (RMSE $=79.3$ ) compared to OK map (RMSE $=79.6)$, making it more appropriate method for mapping. Coordinates of most over-estimated and under-estimated data were as follows: $X=6418000$, $\mathrm{Y}=5062000$ and $\mathrm{X}=6440000, \mathrm{Y}=5054000$ (Figures 7 and 14). Original value of the "depth" variable for most over-estimated data is $195 \mathrm{~m}$, while $\mathrm{OK}$ and UK estimations were $543.2 \mathrm{~m}$ and $543 \mathrm{~m}$, respectively. Most under-estimated data have original "depth" value $1800 \mathrm{~m}$, but $\mathrm{OK}$ and UK estimations were $1286.9 \mathrm{~m}$ and $1285.8 \mathrm{~m}$, respectively.

\section{Discussion}

Structural maps often show a trend in input data since mapped surfaces can have a structural slope towards a cardinal direction, or a number of geological structures can be part of a larger structural unit such as monocline. Therefore, with such set of data marked by a trend, it is advisable to use UK in relation to $\mathrm{OK}$, because this technique was developed precisely to identify the trend in the data (in geology it is a common occurrence), calculate it, i.e. describe it with regression and ultimately do better mapping (e.g., [23]).

The UK technique is also advisable to use when the dependent variable does not meet the criteria of second order stationarity required for most of the Kriging techniques. Second order stationarity means that the middle and the variance are equal in the whole area and that the correlation between any two observations depends only on their relative position in the space. To be honest, the OK also solved such a problem in practice, using local variance for calculating each grid point applied to the applied spatial ellipsoid.

However, the main problem using the UK is size of the analysed area. Very often particular structure is characterised with easily observable geological trend, the most often structural, but sometimes also depositional. In such case, it is easy to numerically (linearly) describe such trend (like on monocline) and apply the UK.

\section{Conclusions}

Regional maps often include numerous structures, each of them characterised with own trend, but also there is one large, regional trend inherent for entire mapped area (like here subdepression). When smaller trends are easily described using regression, large trend can be masked for such type of analyses, especially if there are a few regional faults. The problem of faults is also the typical problem for interpolation software that are cell oriented algorithms 
that try smoothly change values among neighbourhood cells (vs. abrupt fault throws).

For this reason, within the Bjelovar subdepression area, the UK and OK give similar crossvalidation values since faults break the trend in the data, i.e. on the subdepression kilometre-scale, with several regional faults, it is almost impossible to determine a regional trend (i.e. there are more). Hence, the UK's higher accuracy in relation to $\mathrm{OK}$ is on a smaller surface, as it was in the example of the Šandrovac field (e.g., [12]). On the contrary, a whole set of structural maps interpolated using $\mathrm{OK}$ technique at the subdepression level could not be improved by simply re-mapping this area with the UK technique.

However, thanks to the more advanced UK algorithm and very detailed set of structural and thickness maps made in the past, at the level of two e-logs, where the depth differences between the individual structures were not so great and the throws were mostly gradual, the UK technique resulted in the best structural maps made so far (of e-log markers Rs5 and $\Delta$ ). In addition, for such datasets also now exists the new variogram models, which included data residuals. And last, here is shown the advantage of Thiessen polygons as introductory analysis that could precede Kriging interpolation on regional scale. Using such polygons, the geologist can easily recognise the regional trends if exist as well as zones where value transitions could be too large on close distances that regional trends could be meaningful to analyse.

\section{Acknowledgment}

This work represents part of doctoral researching of Dr. Ivana Mesić Kiš. Partially, it was also done by financial supports „Mathematical methods in geology II and III" given by University of Zagreb, Faculty of Mining, Geology and Petroleum Engineering in 2017 and 2018.

\section{References}

[1] Vukotinović, L. (1852): Kamenopisna slika gore Moslavačke (Geological sketch of Moslavačka Mt.). Available at https://www.krizevci.eu/hr_HR/slika/ licnosti/vukotinovic/kamenopis.jpeg.
[2] Malvić, T. (2003): Naftnogeološki odnosi i vjerojatnost pronalaska novih zaliha ugljikovodika u Bjelovarskoj uleknini (Oil-Geological Relations and Probability of Discovering New Hydrocarbon Reserves in the Bjelovar Sag), Ph. D. Thesis. Zagreb: University of Zagreb, Faculty of Mining, Geology and Petroleum Engineering; $123 \mathrm{p}$.

[3] Malvić, T., Rusan, I. (2007): Potential Hydrocarbon Discoveries in Bjelovar Subdepression, Croatia. Search and Discovery, 9, 10133, pp. 1-6.

[4] Malvić, T., Sučić, A., Cvetković, M., Resanović F., Velić, J. (2014): Low permeability Neogene lithofacies in Northern Croatia as potential unconventional hydrocarbon reservoirs. Central European Journal of Geosciences, 6(2), pp. 182-194.

[5] Mesić Kiš, I. (2017): Kartiranje i reinterpretacija geološke povijesti Bjelovarske subdepresije univerzalnim krigiranjem te novi opći metodološki algoritmi za kartiranje sličnih prostora (Mapping and reinterpretation of the geological evolution of the Bjelovar Subdepression by Universal Kriging and new general methodological algorithms for mapping in similar areas), Ph. D. Thesis. Zagreb: University of Zagreb, Faculty of Science; $182 \mathrm{p}$.

[6] Malvić, T. (2011): Geological maps of Neogen sediments in the Bjelovar Subdepression (northern Croatia). Journal of Maps, 7(1), pp. 304-317.

[7] Špelić, M., Malvić, T., Saraf, V., Zalović, M. (2016): Remapping of depth of e-log markers between Neogene basement and Lower/Upper Pannonian border in the Bjelovar Subdepression. Journal of Maps, 12(1), pp. 45-52.

[8] Malvić, T., Đureković, M. (2003): Application of the methods: Inverse distance weighting, ordinary kriging and collocated cokriging in porosity evaluation, and comparison of results on the Beničanci and Stari Gradac fields in Croatia. Nafta, 54(9), pp. 331-340.

[9] Balić, D., Velić, J., Malvić, T. (2008): Selection of the most appropriate interpolation method for sandstone reservoirs in the Kloštar oil and gas field. Geologica Croatica, 61(1), pp. 23-75.

[10] Malvić, T. (2008): Primjena geostatistike u analizi geoloških podataka (Application of geostatistics in geological data analysis). University literature, INA Plc., Zagreb, 103 p.

[11] Husanović, E., Malvić, T. (2014): Review of deterministic geostatistical mapping methods in Croatian hydrocarbon reservoirs and advantages of such approach. Nafta, 65(1), pp. 57-63.

[12] Mesić Kiš, I. (2016): Comparison of Ordinary and Universal Kriging interpolation techniques on a depth 
variable (a case of linear spatial trend), case study of the Šandrovac Field. Rudarsko-geološko-naftni zbornik, 31(2), pp. 41-58.

[13] Thiessen, A.H., (1911): Precipitation for large areas. Monthly Weather Review, 39, pp. 1082-1084.

[14] Chow, V.T., (1964): Handbook of applied hydrology: A compendium of water-resources technology. New York: McGraw-Hill, $1468 \mathrm{p}$.

[15] Brassel K.E., Reif D. (1979): A Procedure to Generate Thiessen Polygons. Geographical Analysis, 11(3), pp. 289-303.

[16] Boots, B.N. (1987): Modifying Thiessen Polygons. The Canadian Geographer, 31(2), pp. 160-169.

[17] Isaaks, E., Srivastava, R. (1989). An Introduction to Applied Geostatistics. New York: Oxford University Press Inc., $561 \mathrm{p}$.

[18] Pannatier, Y. (1996): VARIOWIN - Software for spatial data analysis in 2D. New York: Springer, $91 \mathrm{p}$.
[19] Malvić, T. (2012): Review of Miocene shallow marine and lacustrine depositional environments in Northern Croatia. Geological Quarterly, 56(3), pp. 493-504.

[20] Malvić, T. (2016): Regional turbidites and turbiditic environments developed during Neogene and Quaternary in Croatia. Materiali in geokolje (Materials and geoenvironments), 63, pp. 39-54.

[21] Malvić, T., \& Velić, J. (2011): Neogene tectonics in Croatian Part of the Pannonian Basin and Reflectance in Hydrocarbon Accumulations. Proceedings "New Frontiers in Tectonic Research: At the Midst of Plate Convergence" (Ed., Schattner, U.), InTech, 215-238, Rijeka.

[22] Davis, J.C. (1973). Statistics and Data Analysis in Geology. New York: Wiley, $550 \mathrm{p}$.

[23] Veronesi, F. (2012): 3D Advanced mapping of soil properties. Ph. D. Thesis. Bedford: Cranfield University $2012 ; 159$ p. 
